\title{
ANTIFOULANT PROPERTY OF THE MARINE SPONGE Hymeniacidon heliophila (DEMOSPONGIAE: HALICHONDRIDA)
}

\author{
Suzi Meneses Ribeiro ${ }^{1,2 *}$, Éverson Miguel Bianco ${ }^{3,4}$, Ricardo Rogers ${ }^{l}$, \\ Camilla Ferreira Souza $a^{l}$ and Renato Crespo Pereira ${ }^{1,3}$ \\ ${ }^{1}$ Universidade Federal Fluminense \\ Instituto de Biologia, Departamento de Biologia Marinha \\ (Outeiro de São João Baptista, s/nº, Caixa Postal 100.644, 24.001-970 Rio de Janeiro, RJ, Brasil) \\ ${ }^{2}$ Universidade Federal do Rio de Janeiro \\ Museu Nacional, Departamento de Invertebrados \\ (Quinta da Boa Vista s/nº, São Cristóvão, 20.940-040 Rio de Janeiro, RJ, Brasil) \\ ${ }^{3}$ Universidade Federal Fluminense \\ Instituto de Química, Pós-graduação em Química Orgânica \\ (Outeiro de São João Baptista, s/nº, 24.020-150, Niterói, RJ, Brasil) \\ ${ }^{4}$ Universidade Federal de Santa Catarina \\ Centro de Ciências da Saúde, Pós-graduação em Farmácia - Laboratório de Produtos Naturais \\ (Campus Universitário da Trindade, 88.040-970 Florianópolis, SC, Brasil) \\ *Corresponding author e-mail: suzimr@yahoo.com.br
}

Marine sponges (Porifera) produce a plethora of different chemicals with important biological and ecological roles, such as antipredatory (PAWLIK et al., 1995), antioxidant (LYSEK et al., 2003), allelopathic (ENGEL; PAWLIK, 2000; PAWLIK et al., 2007; CHAVES-FONNEGRA et al., 2008), antimicrobial (THOMPSON et al., 1985; YALÇIN, 2007), and antifoulant (HENRIKSON; PAWLIK, 1998; CHAVES-FONNEGRA et al., 2005), among others.

Hymeniacidon heliophila is a marine sponge found throughout the Atlantic ocean (GINN et al., 1998; LERNER et al., 2005). This species is distributed along the coast of the State of Rio de Janeiro, living in various habitats including some highly polluted ones, such as Guanabara Bay, into which large quantities of untreated sewage have been discharged since the 1950s (BREVES-RAMOS et al., 2005; BORGES et al., 2009).

Several compounds have already been reported for the genus Hymeniacidon, such as peptides, alkaloids, lipids and steroids (INABA et al., 1998; GRANATO et al., 2000; NECHEV et al., 2004; BLUNT et al., 2009), but little is known about their ecological roles. Previous studies have shown that L5-hydroxytryptophan isolated from $H$. heliophila acts as a protection against UV radiation (LYSEK et al., 2003). Crude extract obtained from $H$. heliophila collected in North Carolina (U.S.A.) were assayed as antifoulants in a field experiment, however, no activity wasdetected (HENRIKSON; PAWLIK 1998).
Recently, some crude extracts from $H$. heliophila collected on the Brazilian coast were recorded as active defense against predation by sea urchins, hermit crabs and fishes (RIBEIRO et al., 2010). Based on previous knowledge of the multiple functionality of secondary metabolites from marine organisms, this study reports on the antifouling property of three crude extracts of $H$. heliophila with distinct polarities acting against the byssal attachment of the mussel Perna perna (Linnaeus) (Bivalvia, Mytillidae) (PAUL, 1992; SCHMITT et al., 1995; MCCLINTOCK et al., 2001). This note is the first record of antifoulants from $H$. heliophila in the South Atlantic.

Sponges and mussels were collected by free diving and by hand on Itaipu beach, Niterói city (Rio de Janeiro State, $22^{\circ} 58^{\prime} 19$ '' $\mathrm{S}-43^{\circ} 02^{\prime} 44^{\prime}$ 'W) in July 2005 and freeze-dried to yield $75 \mathrm{~g}$ of dry-mass, which was extracted with $n$-hexane, ethyl acetate and acetone/methanol (1:1), furnishing three extracts named HE, EA and AM, respectively. Laboratory experiments were performed following the method detailed by Da Gama et al. (2003). For each of ten replicates utilized we used two overlapped filter papers (treatment and control) in a Petri dish of $9 \mathrm{~cm}$ diameter. Treatment filters were cut in a chessboard pattern (1.5 cm-side squares) and placed above the control filters which were used whole, without any cut chessboard pattern. Treatment filters were soaked in crude extract diluted in dichloromethane $\left(\mathrm{CH}_{2} \mathrm{Cl}_{2}\right)$, while control filters were washed only with $\mathrm{CH}_{2} \mathrm{Cl}_{2}$. 
The same amount of solvent was used in both filters. The solvent in the filter papers was evaporated at room temperature. To exclude the possibility of solvent influence we also used an independent control, in which no solvent or substance was used in either filter (control or treatment).

A natural concentration of each crude extract was applied in the respective chessboard filter treatment, HE (147 mg; 5.65\%), EA (83 mg; 3.20\%) and AM (154 mg; 5.91\%).

After receiving two filter papers and being filled with sea water, three $P$. perna were added to each Petri dish. The experiments lasted 24 h. Perna perna activity was recorded in terms of the number of byssal threads attached to each substrate (control or treated filter paper, shell of another mussel or border of Petri dish). Mussels were kept in an aquarium for $24 \mathrm{~h}$ after the end of the experiment to verify mortality possibly due to exposure to the crude extracts. Byssus fixation was compared as between control and treated filters by one-way analyses of variance (ANOVA) and Dunnett's post hoc test, $p>0.05$ being considered significant.

The antifouling activity of the crude extracts HE, EA and AM was assayed and significantly inhibited $P$. perna fixation $(p=0.002$ for HE, $p=$ 0.005 for EA and $p=0.009$ for AM). Although there was no significant difference between the effects of the active extracts, the most efficient fraction was HE (Fig. 1).

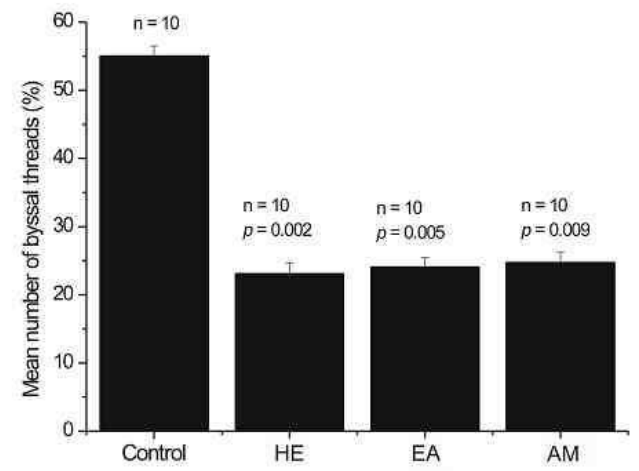

Fig. 1. Mean number of $P$. perna byssal threads (+ standard errors) attached to control and treatment substrata. HE, $n$ hexane; EA, ethyl acetate; and AM, acetone/methanol (1:1) extract of $H$. heliophila. $\mathrm{N}=$ number of replicates and $p=$ significance level.

As the mean number of byssal threads was similar in the three treatments, it is presumed that the effectiveness of the active extracts is equivalent. Extracts of different polarities from the Mediterranean sponges Crambe crambe and Hemimycale columella also showed multiple biological functions, inhibiting cell division and settlement (BECERRO et al., 1997). In North Carolina, the extract of $H$. heliophila was unable to avoid fouling in field tests, but these contrasting results in H. heliophila from the North and South Atlantic might have been influenced by the different methods applied (HENRIKSON; PAWLIK, 1998). Henrikson and Pawlik (1998) used plates with crude extract exposed to natural conditions, and analyzed coverage by invertebrate larvae and algal propagules. Antifouling mechanisms affecting the early stages of organisms may differ from those involved in macroinvertebrate settlement. Latitudinal differences can also alter the chemical composition of organisms, as has been suggested for the sponge Aplysina fulva collected on the Brazilian coast (NUÑEZ et al., 2008). Further chemical studies arenecessary to corroborate this conclusion. Compounds such as cholestanol, debromohymenialdisine, L-5-hydroxytryptophan and manzacidins A-C have been recorded in species of the genus Hymeniacidon; however, the presence of these substances in $H$. heliophila from Rio de Janeiro has not yet been confirmed (KITAGAWA et al., 1983; KOBAYASHI et al., 1991; LYSEK et al., 2003; NECHEV et al., 2004).

It is important to note that both sponges and mussels commonly occur in the same zone on rocky shores, and $H$. heliophila often grows on mussel, but the inverse has not been observed, suggesting that the chemicals extracted from $H$. heliophila play an important ecological role in areas of fierce competition for space.

The various chemical defenses of $H$. heliophila (RIBEIRO et al., 2010, and present study) must also contribute to its survival in polluted areas such as Guanabara Bay, seeing that fouling organisms from those habitats have the ability to cover rapidly surfaces due to the simplicity of community structure in that region (BREVES-RAMOS et al., 2005). Investigations concerning the capability of chemical defenses acting in biological interactions help us to understand the evolutionary strategies that these organisms use to survive in distinct environments.

\section{ACKNOWLEDGEMENTS}

We are gratefull to the Conselho Nacional de Desenvolvimento Científico e Tecnológico (CNPq), Coordenação de Aperfeiçoamento de Pessoal de Nível Superior (CAPES), and the Fundação de Amparo à Pesquisa do Estado do Rio de Janeiro (FAPERJ) for their financial support and research grants; to Juliana Ferrari and Ecidine Alves Barbosa for field and assistance given during the experiments. 


\section{REFERENCES}

BECERRO, M. A.; TURON, X.; URIZ, M. J. Multiple functions for secondary metabolites in incrusting marine invertebrates. J. Chem. Ecol., v. 23, n. 6, p. 1527-1547, 1997.

BLUNT, J. W.; COPP, B. R.; HU, W.; MUNRO M. H. G. NORTHCOTE, P. T.; PRINSEP, M. Marine natural products. Nat. Prod. Rep., v. 26, p. 170-244, 2009.

BORGES, A. C.; SANDERS, C. J.; SANTOS, H. L. R.; ARARIPE, D. R.; MACHADO, W.; PATCHINEELAM Eutrophication history of Guanabara Bay (SE Brazil) recorded by phosphorus flux to sediments from a degraded mangrove area. Mar. Pollut. Bull., v. 58, p. 1739-1765, 2009.

BREVES-RAMOS, A.; LAVRADO, H. P.; JUNQUEIRA, A. O. R.; SILVA, S. H. G. Succession in rocky intertidal benthic communities in areas with different pollution levels at Guanabara Bay (RJ-Brazil). Braz. Arch. Biol. Tech., v. 48, n. 6, p. 951-965, 2005.

CHAVES-FONNEGRA, A.; LÓPEZ-VICTORIA, M.; PARRA-VELANDIA, F.; ZEA, S. Ecología química de las esponjas excavadoras Cliona aprica, C. caribbaea; $C$. delitrix y C. tenuis. Bol. Invest. Mar. Cost., v. 34, p. $43-$ 67, 2005.

CHAVES-FONNEGRA, A.; CASTELLANOS, L.; ZEA, S.; DUQUE, C.; RODRÍGUEZ, J.; JIMÉNEZ, C. Clionapirrolidine $\mathrm{A}$, a metabolite from the encrusting and excavating sponge Cliona tenuis that kills coral tissue upon contact. J. Chem. Ecol., v. 34, p. 1565-1574, 2008.

DA GAMA, B. A. P.; PEREIRA, R. C.; SOARES, A. R.; TEIXEIRA, V. L.; VALENTIN, Y. Y. Is the mussel test a good indicator of antifouling activity? A comparison between laboratory and field assays. Biofouling, v. 19, p. 161-169, 2003.

ENGEL, S.; PAWLIK, J. R. Allelopathic activities of sponges extracts. Mar. Ecol. Progr. Ser., v. 207, p. 273-281, 2000 .

GINN, B. K.; LOGAN, A.; THOMAS, M. H. L.; VAN SOEST, R. W. M. Hymedesmia canadensis (Porifera: Poecilosclerida), a new species among new geographical records from the Bay of Fundy, New Brunswick, Canada. J. Mar. Biol. Assoc. U. K., v. 78, p. 1093-1100, 1998.

GRANATO, A. C.; BERLINK, R. G. S; MAGALHÃES, A.; SCHEFER, A. B.; FERREIRA, A. G.; SANCTIS, B.; FREITAS, J. C.; HAJDU, E.; MIGOTTO, A. E. Produtos naturais das esponjas marinhas Aaptos sp., Hymeniacidon aff. heliophila e do nudibrânquio Doris aff. verrucosa. Quim. Nova., v. 23, n.5, p. 594-599, 2000.

HENRIKSON, A. A; PAWLIK J. R. Seasonal variation in biofouling of gels containing extracts of marine organisms. Biofouling, v. 12, p. 245-255, 1998.

INABA, K.; SATO, H., TSUDA, M.; KOBAYASHI, J. Spongiacidins A-D, new bromopyrrole alkaloids from Hymeniacidon sponge. J. Nat. Prod., v. 61, p. 693-695, 1998.

KITAGAWA, I.; KOBAYASHI, M.; KITANAKA, K; KIDO, M.; KYOGOKU, Y. Marine natural products, XII: on the chemical constituents of the Okinawan marine sponge Hymeniacidon aldis. Chem. Pharm. Bull., v. 31, p. 2321-2328, 1983
KOBAYASHI, J.; KANDA, F; ISHIBASHI, M.; SHIGEMORI, H. Manzacidins A-C, novel tetrahydropyrimidine alkaloids from the Okinawan marine sponge Hymeniacidon sp. J. Org. Chem., v. 56, n. 14 , p. 4574-4576, 1991.

LERNER, C.; MOTHES, B.; CARRARO, J. L. Novos registros e ampliação de limites meridionais de distribuição de poríferos (Porifera, Demospongiae) no Atlântico sudoeste. Rev. Bras. Zool., v. 22, n. 3, p. 596612, 2005.

LYSEK, N.; KINSCHERF, R.; CLAUS, R.; LINDEL, T. L5-Hydroxytryptophan: antioxidant and anti-apoptotic principle of the intertidal sponge Hymeniacidon heliophila. Z. Naturforsch. C., v. 58, p. 568-572, 2003.

MCCLINTOCK, J. B.; BAKER, B. J. (Ed.). Marine chemical ecology. Boca Raton, Fla.: CRC Press, 2001. $610 \mathrm{p}$.

NECHEV, J.; CHRISTIE, W. W.; ROBAINA, R.; DE DIEGO, F.; POPOV, S.; STEFANOV, K. Chemical composition of the sponge Hymeniacidon sanguinea from the Canary Islands. Comp. Biochem. Physiol. A.Mol. Integr. Physiol., v. 137, n. 2, p. 365-374, 2004

NUÑEZ, C. V.; DE ALMEIDA, E. V. R.; GRANATO, A. C.; A, MARQUES, S. O.; SANTOS, K. O.; PEREIRA, F. R.; MACEDO, M. L.; FERREIRA, A. G.; HAJDU, E.; PINHEIRO, U. S.; MURICY, G., PEIXINHO, S.; FREEMAN C. J.; GLEASON, D. F.; BERLINK, R. G. S. Chemical variability within the marine sponge Aplysina fulva. Biochem. Syst. Ecol., v. 36, p. 283-296, 2008.

PAUL, V. J. Ecological roles of marine natural products. New York: Comstock; Cornell University Press, 1992.

PAWLIK, J. R.; CHANAS, B.; TOONEN, R. J.; FENICAL, W. Defenses of Caribbean sponges against predatory reef fish. I. Chemical deterrency. Mar. Ecol. Prog. Ser., v. 127, p. 183-194, 1995.

PAWLIK, J. R.; STEINDLER, L.; HENKEL, T. P.; BEER, S.; ILAN, M. Chemical warfare on coral reefs: Sponge metabolites differentially affect coral symbiosis in situ. Limnol. Oceanogr., v. 52, n. 2, p. 907-911, 2007.

RIBEIRO, M. S.; BIANCO, E. M.; ROGERS, R.; LANEUVILlE, V. T.; PEREIRA, R. C. Chemical defense of Hymeniacidon heliophila (Porifera: Halicondrida) against tropical predators. Braz. J. Oceanogr., v. 58, n. 4, p. 315-321, 2010.

SCHMITT, T. M.; HAY, M. E.; LINDQUIST, N. Constraints on chemically mediated coevolution: multiple functions for seaweed secondary metabolites. Ecology, v. 76, p. 107-123, 1995.

THOMPSON, J. E.; WALKER, R. P.; FAULKNER, D. J. Screening and bioassays for biologically-active substances from forty marine sponges from San Diego, California, USA. Mar. Biol., v. 88, p. 11-21, 1985.

YALÇIN, F. N. Biological activities of the marine sponge Axinella. Hacettepe Univ. J. Fac. Pharm., v. 27, n. 1, p. 47-60, 2007.

(Manuscript received 27 August 2010; revised 27 September 2011; accepted 20 October 2011) 